\title{
International Commodity Prices, Growth, and the Outbreak of Civil War in Sub-Saharan Africa
}

by

Markus Brückner and Antonio Ciccone*

August 2009

\begin{abstract}
To learn more about the effect of economic conditions on civil war, we examine whether Sub-Saharan civil wars are more likely to start following downturns in the international price of countries' main export commodities. The data show a robust effect of commodity price downturns on the outbreak of civil wars. We also find that Sub-Saharan countries are more likely to see civil wars following economic downturns in their main OECD export destinations.
\end{abstract}

Key words: Commodity prices, civil war, Sub-Saharan Africa JEL codes: O0, $\mathrm{P} 0, \mathrm{Q} 0$

\footnotetext{
* UPF and UPF-ICREA. This is a revision of "Growth, Democracy, and Civil War" (CEPR DP 6568, 2007). Contact author antonio.ciccone@upf.edu. Ciccone gratefully acknowledges research support from CREI and CREA. We are grateful to Lars Feld, Marta Reynal-Querol, Andrew Scott, Roland Vaubel, and two referees for useful comments.
} 


\section{Introduction}

Since 1945, civil wars in Sub-Saharan Africa have led to more than 4 million battle deaths (Sarkees, 2000) and probably many more civilian casualties (Eck and Hultman, 2007). What started these wars? The debate has focused on ethnic divisions, fragile institutions, and economic conditions (World Bank, 2003). But precise answers remain difficult. This is especially evident when it comes to the question whether civil wars are partly caused by economic conditions. For example, it is well known that Sub-Saharan Africa has seen many civil wars and poor economic growth by international comparisons (United Nations Economic Commission for Africa, 1999; World Bank, 2003). Also, countries with an especially bad growth record in the region have had more civil wars. But this does not prove that civil wars are started by worsening economic conditions because civil wars and poor economic growth might be caused by the same factors (Acemoglu, 2005). Moreover, most factors raising the chances of civil war will lower investment and aggregate GDP, and economic conditions may therefore be the result_rather than cause-of civil war in SubSaharan Africa.

To learn more about the effect of economic conditions on Sub-Saharan African civil wars, we examine whether civil wars are more likely to start following downturns in the international price of countries' main exports commodities. That commodity price downturns cause rapidly worsening economic conditions in many Sub-Saharan African economies has been shown by Deaton and Miller (1995) and Deaton (1999). But do commodity price downturns also lead to the outbreak of civil wars? A preliminary piece of evidence comes from Burundi, Rwanda, and Uganda, the three Sub-Saharan African countries most dependent on coffee exports. After the international coffee price dropped by over 50 percent between 1997 and 2000, civil wars broke out in Burundi in 2000, in Rwanda in 2001, and in Uganda in 2002. This was not the first time that civil wars in these countries were preceded by drops in international coffee prices. The 1991 civil wars in Rwanda and Uganda began after a 40 percent fall in coffee prices between 1988 and 1991.

The evidence from Burundi, Rwanda, and Uganda alone is not conclusive as politics and geography may have made civil war especially likely (Herbst, 2000; Diamond, 2005; 
Kamola, 2007; Robins, 2008). ${ }^{1}$ We therefore use data on the international prices of a wide range of commodities from the IMF and UNCTAD to calculate fixed-weight export-price indices for 39 Sub-Saharan countries for the 1980-2006 period (IMF) and the 1960-2006 period (UNCTAD). This allows us to ask whether Sub-Saharan African countries experiencing downturns in the international prices of their commodity exports were subsequently more likely to see civil wars. We find that downturns in international commodity prices did make civil war onset more likely, and that this result is robust to accounting for cross-country differences in the probability of civil war; for country-specific time trends; and for common shocks to the likelihood of civil war across Sub-Saharan Africa. For example, between 1981 and 2006, a 20 percent drop in countries’ export price indices raised the probability of civil war outbreak by around 2.8 percentage points. To put this into perspective, the "background" probability of a civil war outbreak in Sub-Saharan Africa over the 1981-2006 period was about 2.8 percent, and the probability of a drop in the export price index larger than 20 percent about 10 percent. Hence, there was approximately a 10 percent chance of a drop in export prices that increased the probability of a civil war by 100 percent of the background probability.

Our baseline analysis presumes that international commodity prices do not reflect changes in the probability of future civil wars in Sub-Saharan African exporting countries. This condition would be violated if civil war risk had a significant effect on international commodity prices because of expected civil-war-related supply restrictions. But in this case civil wars in exporting countries should be more likely following rising commodity prices, while we find that civil wars are more likely following falling commodity prices. Also, it is straightforward to restrict the empirical analysis to commodities where Sub-Saharan African countries produce a small share of world supply (less than 3 percent). We find that our results continue to hold in this case.

Deaton and Miller (1995) and Deaton (1999) have shown that downturns in international commodity prices lead to lower economic growth in Sub-Saharan African exporting countries. Moreover, we find that per capita GDP growth of Sub-Saharan African countries

\footnotetext{
${ }^{1}$ Also, all three countries depend on the same export commodity (coffee). Other examples of civil wars that broke out after declines in the price of countries' main commodity export are Angola, where the civil war in 1998 followed a 25 percent drop in the price of oil, and Sudan, where the civil war in 1983 followed a 15 percent drop in the price of cotton.
} 
also turns out to be strongly affected by GDP growth of their main OECD export destinations, even after accounting for international growth shocks (see Acemoglu et al., 2008, for similar evidence in a wider sample). We can therefore estimate the effect of lower economic growth on the likelihood of civil war outbreak under the identifying restriction that international commodity prices and OECD growth affect civil war onset through aggregate GDP growth only (once we control for country-specific fixed effects, time trends, and common shocks). Formal tests of this identifying restriction yield that it cannot be rejected.

Our work aims to contribute to the literature on the link between economic conditions and civil war (e.g. Collier and Hoeffler, 1998, 2004; Sambanis, 2002; Fearon and Laitin, 2003; Miguel, Satyanath, and Sergenti, 2004; Hegre and Sambanis, 2006). Within this literature, we are closest to Miguel, Satyanath, and Sergenti (2004). They examine the link between economic growth and civil war in Sub-Saharan Africa exploiting that economic growth in the region depends strongly on rainfall growth. An important difference between their approach and ours is that rainfall shocks are transitory, while international commodity prices revert to their mean only very slowly, if at all (see Cashin, Liang, and McDermott, 2000). ${ }^{2}$ Hence, economic downturns following falling commodity prices tend to be long lasting. An important difference between our empirical results and those of Miguel et al. is that rainfall growth does no longer explain civil war onset when we account for timevarying factors that affect the probability of civil war throughout Sub-Saharan Africa; the effect of commodity price downturns on civil war onset, on the other hand, is robust to common economic, social, or political factors driving civil war onset in Sub-Saharan Africa.

Our paper is also related to the literature on the natural resource curse. One strand of this literature investigates whether abundant natural resources make civil war onset more likely, see for example, Collier and Hoeffler (2004), Fearon (2005), Humphrey (2005), Ross (2006), De Soysa and Neumayer (2007), Brunnschweiler and Bulte (2008). According to the latest evidence, there does not appear to be a robust link between natural resource wealth

\footnotetext{
${ }^{2}$ This is also the case for the commodity prices in our sample. Using the augmented DickeyFuller test, we cannot reject a unit root for any of the international price series in our sample.
} 
and civil war. ${ }^{3}$ Our analysis differs in that we focus on the within-country link between the value of primary production (due to fluctuation in international prices) and civil war outbreak.

There is an emerging literature on the link between civil conflict and commodity prices. Angrist and Kugler (2008) and Dube and Vargas (2008) present studies for Columbia. Angrist and Kugler find that Columbian municipalities that saw an increase in coca prices also experienced a surge in violence. Dube and Vargas find the same result for Columbian municipalities with oil, coal, or gold production following a rise in the international prices of these commodities. But when they consider agricultural commodities like coffee, sugar, bananas, and tobacco, they tend to find that higher international prices reduce violence. ${ }^{4}$

Besley and Persson (2008) examine the effect of commodity export prices on civil war incidence and onset across a wide range of countries. Three main differences with our work are that Besley and Persson are interested in the effect of export prices conditional on income, that they focus on civil war incidence, and that their empirical analysis takes income as exogenous. ${ }^{5}$ Assuming such exogeneity is difficult for the Sub-Saharan African countries we focus on as income growth is likely to respond to the risk of civil war. Estimating the effect of international commodity prices conditional on income growth therefore requires an instrument for growth. We take a step in this direction by exploiting that income growth across Sub-Saharan African countries is strongly related to GDP growth across OECD countries they export to. We find that international export prices do not affect civil war onset conditional on income growth, which is consistent with Besley and Persson's result that export prices do not affect civil war onset once income is accounted for.

\footnotetext{
${ }^{3}$ There is some evidence of a positive link between the abundance of certain exhaustible resources and civil war however.

${ }^{4}$ When we split commodities into exhaustible resources and agricultural commodities we find that higher international prices reduce the chances of civil war for both groups of commodities. The effect of agricultural commodities is statistically significant. Regarding the effect of natural resources, we can neither reject the hypothesis that the effect is identical to that of agricultural commodities nor the hypothesis that the effect is equal to zero.

${ }^{5}$ See also Frank (2006) who considers the link between commodity prices and civil war in a wide cross-section of countries between 1959 and 1997. He does not control for country fixed effects and common trends in civil war risk however.
} 


\section{Data and Measurement}

Civil conflict. Data on civil conflict is obtained from the UCDP/PRIO Armed Conflicts 2007 Dataset of the International Peace Research Institute's (PRIO) Centre for the Study of Civil War and the Uppsala Conflict Data Program (UCDP). ${ }^{6}$ The UCDP/PRIO Armed Conflict Database defines civil conflict as a "contested incompatibility which concerns government and/or territory where the use of armed force between two parties, of which at least one is the government of a state, results in at least 25 battle deaths." ${ }^{7}$ The database records both incidence and onset of minor conflicts (25 to 999 battle-related deaths per year) as well as civil wars (at least 1000 battle-related deaths per year). While UCDP/PRIO does not provide information on the exact number of battle deaths, it indicates whether the conflict reached a cumulative death toll of more than 1000 battle deaths. In our sample none of the minor conflicts reached this cumulative death toll, which indicates that these are lowintensity conflicts rather than large-scale intra-state wars. To capture civil war outbreak, we define a year $t$ civil war onset indicator for country $c$ that is unity if there is a civil war in $t$ but not in $t-1$, and zero if there is no civil war in $t$ and $t-1$; if there is a civil war in $t-1$, the year $t$ civil war onset indicator is not defined.

International commodity price growth. We construct an international commodity price index for each of the 39 Sub-Saharan African countries in our sample following Deaton (1999). The starting point is monthly international commodity price data for 19 commodities for the 1980-2006 period from the International Monetary Fund (2009). Averaging across all observations in a calendar year yields an annual price series for each commodity $i, P_{i, t}$ (the 1990 value is set equal to unity for all commodities). ${ }^{8}$ We then obtain each country's export share of these commodities from Deaton for 1990 and, for countries and commodities not covered by Deaton, from the UN Commodity Trade Statistics Database for the year closest

\footnotetext{
${ }^{6}$ The dataset is available at http://new.prio.no/CSCW-Datasets/Data-on-Armed-Conflict.

${ }^{7}$ See www.prio.no/cwp/ArmedConflict or www.pcr.uu.se for more on the definition and coding of civil conflicts.

8 The commodities are: aluminium, bananas, cocoa, coffee, copper, cotton, fish, gold, groundnuts, iron, livestock, nickel, oil, phosphates, sugar, tea, tobacco, wood, uranium. The data comes from http://www.imf.org/external/np/res/commod/externaldata.csv.
} 
to 1990 (commodities and years are listed in the Appendix Table). This allows us to calculate the commodity price index for country $c$ in year $t$ as ComPrice Cot $_{i=1}^{19} \sum_{c i} P_{i t}$, where $\omega_{c, i}$ is the time-invariant export share of commodity $i$ in country $c .{ }^{9}$ The annual growth rates of the commodity price index are our main explanatory variables. The IMF commodity price data starts in 1980. To present results for a longer time period we also use United Nations Conference on Trade and Development (2009) data.

Export-weighted OECD growth. We construct an export-weighted GDP growth rate of OECD trading partners for each of the Sub-Saharan African countries in our sample. For Sub-Saharan countries $c$ and year $t$, the export-weighted GDP growth rate of OECD trading partners $j$ is ExportsOECD $D_{c t}=\sum_{j=1}^{30} \theta_{c j} G D P G r o w t h_{j t}$, where $\theta_{c, j}$ is the (time-invariant) exports of country $c$ to country $j$ as a share of country c's GDP in 1990 and GDPGrowth s.t $_{j, t}$ the GDP growth rate of OECD countries $j$ in constant US\$. ${ }^{10}$ The GDP data come from the World Development Indicators (2009) and the export data from the OECD Statistics (2009). ${ }^{11}$ This variable is closely related to Acemoglu et al.'s (2008) trade-weighted world income instrument.

Rainfall growth. Our data on rainfall growth covers the 1979-2006 period and comes from the NASA Global Precipitation Climatology Project (GPCP), Version 2 (Adler et. al, 2003). ${ }^{12}$ The rainfall data is that of Miguel, Satyanath, and Sergenti (2004) but covers a longer time period. The GPCP rainfall data are based on data from satellites and rain gauges. Alternative rainfall data sets are based on rain gauges only, which has the disadvantage that gauge coverage in many Sub-Saharan African countries is very sparse and that the number of reporting stations may be affected by socio-economic conditions.

Income growth. Data for real GDP per capita growth are taken from the Penn World Tables 6.2 for the 1961-2004 period (the data stops in 2004) and from the World Development

\footnotetext{
${ }^{9}$ The commodities and weights used for each country are listed in the Appendix Table.

${ }^{10}$ We use GDP in constant US\$ to capture international purchasing power.

${ }^{11}$ Available at http://stats.oecd.org/WBOS/index.aspx.

${ }^{12}$ The data comes from http://precip.gsfc.nasa.gov.
} 
Indicators (2009) for the 2004-2006 period. ${ }^{13}$ Table 1 provides some descriptive statistics of our data.

\section{Estimation Framework}

Our main estimating equation links the indicator for civil war onset to commodity price growth and other controls,

$$
\text { ConflictOnset }_{c t}=\alpha_{c}+\beta_{c} t+\delta_{t}+\gamma \text { ComPriceGrowth }_{c t}+\varepsilon_{c t}
$$

where ComPriceGrowth is the growth rate of international commodity prices over the three years leading up to $t$ (we also estimate separate effects for annual growth rates). Our estimates account for country fixed effects $\left(\alpha_{c}\right)$, country-specific trends $\left(\beta_{c} t\right)$, and shocks that are common to Sub-Saharan African countries $\left(\delta_{t}\right) . \varepsilon_{c t}$ is a disturbance term that can be serially correlated.

In addition to (1), we also estimate an equation with GDP growth instead of commodity price growth on the right-hand-side. Our main method of estimation is two-stage least squares with commodity price growth as an instrument for GDP growth. Notice that linear two-stage least squares is the preferred method of estimation despite the dichotomous explanatory variable, as alternative approaches require strong specification assumptions (Angrist and Krueger, 2001; Wooldridge, 2002).

\section{Empirical Results}

International commodity prices and civil war onset. Table 2 contains our results on the effect of international commodity prices on civil war onset. In column (1) we link civil war onset in year $t$ to the growth of international commodity prices over the 3 previous years, controlling for country fixed effects, country-specific time trends and year fixed effects (we

${ }^{13}$ The WDI data start in 1980 but are unavailable for two of the countries in our sample. Combining data allows us to work with all countries in our sample and go up to 2006. We would still get significant first-stage and second-stage estimates however if we used the PWT or WDI data only. 
stop at 3 lags as additional lags are never significant). The estimates show that the risk of civil war outbreak is higher when the price of export commodities drops. The statistically significant effects at $t$ and $t$-2 imply that a 20 percent drop in countries' commodity price indices is associated with an increase in the probability of a civil war onset of about 1.1 percentage points on impact (this number is the estimate in Table 2 column (1) in the paper multiplied by 0.20 ) and an additional 1.7 percentage points with a lag. Summing the effect on impact and the lagged effect yields a total increase in the probability of civil war of 2.8 percentage points. To put this into perspective, the "background" probability of a civil war outbreak in Sub-Saharan Africa over the 1981-2006 period is 2.8 percent. Hence, a 20 percent drop in countries' commodity price index raises the probability of civil war by 100 percent of the background probability. As 10 percent of our observations show a drop of the commodity price index larger than 20 percent, the data indicate a 10 percent chance of a drop in export prices that increases the probability of a civil war onset by 100 percent of the background probability.

In column (2), we look at the link between rainfall growth and civil war onset. We do not find any significant effects, which contrasts with Miguel, Satyanath, and Sergenti (2004). The difference arises because Miguel, Satyanath, and Sergenti do not control for common Sub-Saharan African risk factors. ${ }^{14}$ In column (3) we show that the significant effect of international commodity price growth remains statistically significant when controlling for rainfall growth which continues to be insignificant. Column (4) shows that this is also the case when using the level of rainfall rather than the growth rate. ${ }^{15}$

In column (5) we relate civil war onset in year $t$ to the growth of countries' commodity price indices over the 3 previous years. This specification yields that a 25 percent drop in the international commodity price index over a 3-year period raises the probability of civil war onset by about 1.5 percentage points -50 percent of the background probability of civil war in Sub-Saharan Africa (10 percent of the observations have 3-year drops in excess of 25

\footnotetext{
${ }^{14}$ We find that year effects are always jointly significant at the 1 percent level at least.

${ }^{15}$ Ciccone (2008) argues that interannual rainfall growth is not the right variable to examine whether negative rainfall shocks make civil war outbreak more likely. This is because rainfall shocks are transitory, which implies that rainfall growth may be low either because of a negative rainfall shock or because of mean reversion following a positive shock.
} 
percent). ${ }^{16}$ Column (6) controls for average rainfall levels over the 3 previous years and finds that 3-year commodity price growth continues to have a significant negative effect on civil war onset while 3 -year rainfall is insignificant. ${ }^{17}$

Table 3 looks at the effect of 3-year commodity price growth on civil war outbreak using a variety of limited dependent variable estimators. Not all of them allow for fixed effects, which is why some of the models estimated in the table do not include controls. For comparison with the limited dependent variable estimates without controls, we report leastsquares estimates without controls in column (1). Column (2) reports the marginal effect in the corresponding probit model (probit is inconsistent with fixed effects, see Wooldridge, 2002). It can be seen that the probit result is similar to the least-squares result in column (1). In column (3) we use a logit model without controls and find a marginal effect that is identical to the probit model in column (2). Column (4) reports the non-marginal effect of the logit model for comparison with the rare-events logit estimator of King and Zeng (2001) in column (5). King and Zeng argue that their estimator is preferable when the outcome of interest is a rare event as logit can be biased upwards in this case (the average probability of a civil war onset during 1980-2006 period is 2.8 percent). Our results show that this does not appear to be a concern in our application. ${ }^{18}$

Our most important limited dependent variable results are the conditional fixed effects logit estimates in columns (6) and (7). These estimates have the advantage of being consistent in the presence of fixed effects, see Wooldridge (2002). This approach yields statistically significant effects of 3-year commodity price growth on civil war outbreak whether we control for country fixed effects only (column (6)) or country fixed effects as

\footnotetext{
${ }^{16}$ We have tested whether the impact of negative price shocks is different from the impact of positive price shocks by including in the regression an interaction term between the 3-year commodity price growth rate and an indicator function that is 1 if and only if 3-year commodity price growth is strictly negative. We find that this interaction term is insignificant while the linear effect on the commodity price growth rate remains significant. Hence, we do not find evidence that the impact of negative price shocks is significantly different from the impact of positive price shocks.

${ }^{17}$ We would obtain the same result if we controlled for 3-year rainfall growth.

18 We have also done a Monte-Carlo study simulating time-series data that matches the average rate of civil war outbreak and our sample size to ensure that the rare-events nature of civil war onsets does not bias inference. We find that we correctly rejected the null hypothesis of no significant effect at the right rate for the 1 percent level, the 5 percent level, as well as the 10 percent level.
} 
well as country-specific time trends and year fixed effects (column (7)). ${ }^{19}$ It is also important to note that the logit effect is strongest quantitatively and statistically in column (7) where we account for all controls (see columns (4) and (6) for comparison). Hence, to isolate the effect of commodity prices on civil war, it is important to control for country-specific time trends as well as common shocks.

Economic growth and civil war onset. Table 4 examines the link between Sub-Saharan economic growth and the outbreak of civil war. The table shows least-squares results and two-stage least-squares estimates using commodity price index growth as an instrument for economic growth. Column (1) estimates the first-stage relation between 3-year commodity price growth and GDP per capita growth in Sub-Saharan Africa, controlling for country fixed effects (which capture country-specific differences in steady state growth rates), country-specific time trends (capturing convergence effects), and year fixed effects (which capture the world business cycle and other shocks that are common to Sub-Saharan African countries). The main finding is that falling international commodity prices reduce economic growth rates, which is in line with Deaton and Miller (1995) and Deaton (1999). The point estimate implies that a 25 percent drop in countries’ commodity price indices over a 3-year period reduces real per capita GDP growth by 0.7 percentage points. This effect is highly statistically significant (the t-statistic is 3.97).

Column (2) contains the least-squares effect of GDP per capita growth on civil war onset. The point estimate is negative and significant at the 95 percent confidence level. This cannot be taken as evidence of a causal effect of per capita GDP growth on civil war risk however for several reasons. For example, the least-squares effect may overstate the causal effect because a greater likelihood of civil war may reduce investment and future economic growth. But it is also possible that the causal effect is understated because of classical measurement error bias (measurement error is known to be particularly severe in SubSaharan African national account statistics, see Heston, 1994, and Deaton, 2005).

Column (3) presents instrumental-variables (two-stage least-squares) estimates of the effect of GDP per capita growth on civil war risk. We find that a 1 percent drop in GDP

19 Note that coefficients do not represent marginal effects since this would require knowledge of the distribution of the fixed effects (see Wooldridge, 2002, p. 492). 
increases the risk of civil war onset by over 2 percentage points (controlling for country fixed effects, country-specific time trends, and year fixed effects). This estimate is statistically significant at the 95 percent confidence level and, in absolute value, more than 5 times the least-squares effect in column (2). ${ }^{20}$

It turns out that per capita GDP growth of Sub-Saharan African countries is also strongly affected by GDP growth of their main OECD export destinations. This can be seen in Table 5 , column (1), where higher OECD growth has a positive and highly statistically significant effect on Sub-Saharan per capita GDP growth, even after controlling for country fixed effects, country time trends, and year effects. (Moreover, as shown in column (2), higher OECD growth also lowers the likelihood of civil war onset.) This motivates our two-stage least-squares analysis in column (3), which uses both commodity price growth and OECD growth as an instrument for Sub-Saharan African GDP per capita growth. The result in column (3) shows that this also yields a statistically significant, negative effect of GDP growth on the probability of civil war outbreak. Compared to column (3), the effect is statistically stronger but smaller in absolute value. Most importantly, according to the test of overidentifying restrictions reported in the table, the exclusion restriction cannot be rejected at standard confidence levels. ${ }^{21}$

Table 6 repeats the empirical analysis for the onset of civil conflict. Civil conflict includes both events classified as civil wars and (relatively) minor conflicts. In column (1) we report first-stage effects for this sample, which turn out to be highly statistically significant. In column (2) we find that both commodity price growth and OECD growth have a negative reduced-form effect on civil conflict onset, but that only OECD growth is statistically significant. Column (3) reports the least-squares effect of GDP growth on civil conflict onset and column (4) the two-stage least-squares estimate. According to the twostage least-squares estimate a 1 percent decrease in per capita GDP implies an increase in

\footnotetext{
${ }^{20}$ We have also done the second stage regression controlling for a time-varying measure of export diversification which we construct from the NBER UN Trade statistics database. We find that per capita GDP growth continues to show up in the second stage as having a statistically significant, negative effect on civil war onset. Annual changes in export diversification, on the other hand, turn out to be statistically insignificant.

${ }^{21}$ We have also examined whether international commodity price shocks could affect civil war onset through their effect on government (military) expenditures or foreign aid but did not find any significant effects.
} 
the probability of civil conflict outbreak of more than 0.6 percentage points, which is about twice the least-squares effect in absolute value.

In Table 7 we examine the link between commodity prices, economic growth, and civil war/conflict for the 1961-2006 period using UNCTAD commodity price data. Panel A shows estimates for civil war onset and Panel B estimates for the onset of civil conflict. The effect of international commodity price growth is negative and statistically significant in both cases. We also find a statistically significant negative effect of OECD export demand growth on civil war and civil conflict onset. In columns (3) and (4) we estimate the effect of GDP per capita growth on civil war/conflict outbreak using a least-squares approach and an instrumental-variables approach respectively. Both approaches yield a statistically significant, negative effect of economic growth on civil war/conflict onset, and instrumentalvariables estimates are more than twice the corresponding least-squares estimates in absolute value. Moreover, the instrumental-variables effects in Table 7 are similar to those in Tables 5 and 6 (smaller for civil war onset and slightly larger for civil conflict onset). Hence, our estimates for the 1961-2006 period continue to indicate a link between the outbreak of civil war/conflict and economic shocks related to international commodity prices and OECD demand for Sub-Saharan African exports.

\section{Conclusion}

Our goal has been to learn more about the effect of economic conditions on civil war outbreak. To do so, we examined whether civil wars were more likely following exogenous downturns in international prices of and demand for Sub-Saharan African countries' main export commodities. Our empirical results indicate that negative shocks did make civil war more likely. For example, between 1981 and 2006, a 20 percent year-to-year drop in countries' export price indices raised the probability of civil war outbreak by around 2.8 percentage points. To put this into perspective, the "background" probability of a civil war outbreak in Sub-Saharan Africa over this period was about 2.8 percent, and the probability of a drop in the export price index larger than 20 percent about 10 percent. Hence, there was approximately a 10 percent chance of a drop in export prices that increased the probability of a civil war by 100 percent of the background probability. 


\section{References}

Acemoglu, D. (2005). “Evaluation of World Bank Research.” in A. Deaton, K. Rogoff, A. Banerjee, N. Lustig, eds. Evaluation of World Bank Research Over the Last Decade.

Acemoglu, D. S. Johnson, J. Robinson, and P. Yared (2008). "Income and Democracy." American Economic Review 98 (3): 808-842.

Adler, R.F., G.J. Huffman, A. Chang, R. Ferraro, P. Xie, J. Janowiak, B. Rudolf, U. Schneider, S. Curtis, D. Bolvin, A. Gruber, J. Susskind, P. Arkin, and E. Nelkin (2003). "The Version 2 Global Precipitation Climatology Project (GPCP) Monthly Precipitation Analysis (1979-Present).” Journal of Hydrometeorology 4: 1147-1167.

Andrews, D. and J. Stock (2005). "Inference with Weak Instruments.” NBER Technical Paper No. 0313.

Angrist, J. and A. Krueger (2001). "Instrumental Variables and the Search for Identification: From Supply and Demand to Natural Experiments.” Journal of Economic Perspectives 15 (4): 69-85.

Angrist, J. and A. Kugler (2008). "Rural Windfall or a New Resource Curse? Coca, Income and Civil Conflict in Columbia.” Review of Economics and Statistics 90 (2): 191-215.

Besley, T. and T. Persson (2008). "The Incidence of Civil War: Theory and Evidence.” unpublished manuscript, Stockholm University.

Brückner, M. and A. Ciccone (2007). "Growth, Democracy, and Civil War.” CEPR Discussion Paper No. 6568.

Brunnschweiler, C. and E. Bulte (2008). "Linking Natural Resources to Slow Growth and More Conflict.” Science 320: 616-617.

Cashin, P. H. Liang, and J. McDermott (2000). "How Persistent Are Shocks to World Commodity Prices?” IMF Staff Paper 47 (2): 177-217.

Ciccone, A. (2008) “Transitory Economic Shocks and Civil Conflict.” CEPR Discussion Paper No. 7081.

Collier, P. and A. Hoeffler (1998). "On Economic Causes of Civil War.” Oxford Economic Papers 50 (3): 563-573.

Collier, P. and A. Hoeffler (2004). "Greed and Grievance in Civil War.” Oxford Economic Papers 56 (4): 563-596.

Diamond, J. (2005). Collapse: How Societies Choose to Fail or Succeed. New York: Penguin Press.

Deaton, A. (1999). “Commodity Prices and Growth in Africa." Journal of Economic Perspectives 13 (3): 23-40.

Deaton, A. (2005). "Measuring Poverty in a Growing World (Or Measuring Growth in a Poor World).” Review of Economics and Statistics 87 (1): 1-19.

Deaton, A. and R. Miller (1995). International Commodity Prices, Macroeconomic Performance, and Politics in Sub-Saharan Africa. Princeton, NJ: Princeton Studies in International Finance, No 79.

De Soysa, I. and E. Neumayer (2007). "Resource Wealth and the Risk of Civil War Onset: Results from a New Dataset of Natural Resource Rents, 1970-1999.” Conflict Management and Peace Science 24 (3): 201-218.

Dube, O. and J. Vargas (2008). "Commodity Price Shocks and Civil Conflict: Evidence From Colombia.” unpublished manuscript, Harvard University.

Eck, K. and L. Hultman (2007). "One-Sided Violence Against Civilians in War: Insights from New Fatality Data.” Journal of Peace Research 44 (2): 233-246. 
Fearon, J. (2005). "Primary Commodity Exports and Civil War." Journal of Conflict Resolution 49: 483-507.

Fearon, J. and D. Laitin (2003). “Ethnicity, Insurgency and Civil War.” American Political Science Review 97 (1): 75-90.

Frank, R. (2006). “Commodity Prices, State Capacity, and Civil War. The Interaction of Economic Diversification, Price Uncertainty, and Violence.” Paper prepared for the $64^{\text {th }}$ Annual Meeting of the Midwest Political Science Association.

Hegre, H. and N. Sambanis (2006). "Sensitivity Analysis of the Empirical Results on Civil War Onset.” Journal of Conflict Resolution 50 (4): 508-535.

Herbst, J. (2000). States and Power in Africa. Princeton: Princeton University Press.

Heston, A. (1994). "A Brief Review of Some Problems Using National Accounts Data in Level of Output Comparisons and Growth Studies.” Journal of Development Economics 44 (6): 29-52.

Humphrey, J. (2005). “Natural Resources, Conflict, and Conflict Resolution.” Journal of Conflict Resolution 49 (4): 508-537.

International Monetary Fund (2009). Commodity Price Series. Online Database.

Kamola, I. (2007). "The Global Coffee Economy and the Production of Genocide in Rwanda.” Third World Quarterly 28: 571-592.

King, G. and L. Zeng (2001). “Logistic Regression in Rare Events Data.” Political Analysis 9 (2): $137-163$

Miguel, E., S. Satyanath, and E. Sergenti (2004). "Economic Shocks and Civil Conflict: An Instrumental Variables Approach.” Journal of Political Economy 112 (41): 725-753.

OECD (2009). OECD.StatExtracts. Online Database.

United Nations Economic Commission for Africa (1999). The Challenges of Poverty Reduction and Sustainability. Economic Report on Africa 1999, UNECA.

United Nations Conference on Trade and Development (2009). Commodity Price Series. Online Database.

Robins, R. (2008). Global Problems and the Culture of Capitalism. Boston: Allyn\&Bacon Press.

Ross, M. (2006). “A Closer Look at Oil, Diamonds, and Civil War.” American Political Science Review 9: 265-300.

Sambanis, N. (2002). "A Review of Recent Advances and Future Directions in the Quantitative Literature on Civil War. Defence and Peace Economics 13 (3): 215-243.

Sarkees, M. (2000). “The Correlates of War Data on War: An Update to 1997." Conflict Management and Peace Science 18 (1): 123-144.

Wooldridge, J. (2002). Econometric Analysis of Cross Section and Panel Data. Cambridge, Mass.: MIT Press.

World Bank (2003). Breaking the Conflict Trap: Civil War and Development Policy. Oxford University Press.

World Bank (2009). World Development Indicators. Online Database. 
Table 1. Descriptive Statistics

\begin{tabular}{lccc}
\hline & Mean & Std. Dev. & Obs. \\
Civil War Onset 1981-2006 (PRIO/UPSALLA 2007) & 0.028 & 0.166 & 814 \\
Civil Conflict Onset 1981-2006 (PRIO/UPSALLA 2007) & 0.055 & 0.228 & 688 \\
Civil War Onset 1961-2006 (PRIO/UPSALLA 2007) & 0.021 & 0.144 & 1332 \\
Civil Conflict Onset 1961-2006 (PRIO/UPSALLA 2007) & 0.052 & 0.223 & 1150 \\
International Commodity Price Growth, Index (IMF) & 0.059 & 0.356 & 914 \\
International Commodity Price Growth, Index (UNCTAD) & 0.186 & 0.509 & 1444 \\
Rainfall Growth, Adler et al. (2003) & 0.022 & 0.218 & 914 \\
OECD GDP Growth 1981-2006, WDI (2009) and OECD (2009) & 2.335 & 6.608 & 914 \\
OECD GDP Growth 1961-2006, WDI (2009) and OECD (2009) & 2.517 & 6.693 & 1444 \\
Real Per Capita GDP Growth 1981-2006 (PWT 6.2 and WDI (2009)) & 0.028 & 0.089 & 914 \\
Real Per Capita GDP Growth 1961-2006 (PWT 6.2 and WDI (2009)) & 0.006 & 0.088 & 1444 \\
\hline
\end{tabular}




\begin{tabular}{|c|c|c|c|c|c|c|}
\hline \multicolumn{7}{|c|}{$\underline{\text { Civil War Onset }}$} \\
\hline & (1) & $(2)$ & (3) & (4) & (5) & (6) \\
\hline & LS & LS & LS & LS & LS & LS \\
\hline Commodity Price Growth, $t$ & $\begin{array}{l}-0.055^{*} \\
(-1.91)\end{array}$ & & $\begin{array}{l}-0.054^{*} \\
(-1.86)\end{array}$ & $\begin{array}{l}-0.051^{*} \\
(-1.80)\end{array}$ & & \\
\hline Commodity Price Growth, t- 1 & $\begin{array}{l}-0.028 \\
(-0.79)\end{array}$ & & $\begin{array}{l}-0.029 \\
(-0.81)\end{array}$ & $\begin{array}{l}-0.027 \\
(-0.75)\end{array}$ & & \\
\hline Commodity Price Growth, t-2 & $\begin{array}{c}-0.087 * * \\
(-2.23)\end{array}$ & & $\begin{array}{c}-0.087 * * \\
(-2.21)\end{array}$ & $\begin{array}{c}-0.085^{* *} \\
(-2.13)\end{array}$ & & \\
\hline $\begin{array}{l}\text { 3-Year Commodity Price } \\
\text { Growth }\end{array}$ & & & & & $\begin{array}{c}-0.059 * * \\
(-2.24)\end{array}$ & $\begin{array}{c}-0.058^{* *} \\
(-2.19)\end{array}$ \\
\hline Rainfall Growth, t & & $\begin{array}{l}-0.007 \\
(-0.31)\end{array}$ & $\begin{array}{l}-0.006 \\
(-0.28)\end{array}$ & & & \\
\hline Rainfall Growth, t-1 & & $\begin{array}{l}-0.005 \\
(-0.21)\end{array}$ & $\begin{array}{l}-0.005 \\
(-0.20)\end{array}$ & & & \\
\hline Rainfall Growth, t-2 & & $\begin{array}{l}-0.018 \\
(-0.56)\end{array}$ & $\begin{array}{l}-0.015 \\
(-0.47)\end{array}$ & & & \\
\hline Log Rainfall, t & & & & $\begin{array}{l}-0.031 \\
(-0.93)\end{array}$ & & \\
\hline Log Rainfall, t-1 & & & & $\begin{array}{l}-0.047 \\
(-1.60)\end{array}$ & & \\
\hline Log Rainfall, t-2 & & & & $\begin{array}{l}-0.007 \\
(-0.15)\end{array}$ & & \\
\hline 3-Year Rainfall & & & & & & $\begin{array}{l}-0.091 \\
(-1.52)\end{array}$ \\
\hline Country FE & Yes & Yes & Yes & Yes & Yes & Yes \\
\hline Time Trends & Yes & Yes & Yes & Yes & Yes & Yes \\
\hline Year FE & Yes & Yes & Yes & Yes & Yes & Yes \\
\hline Adj. R-squared & 0.270 & 0.262 & 0.271 & 0.273 & 0.271 & 0.272 \\
\hline MSE & 0.142 & 0.142 & 0.142 & 0.141 & 0.142 & 0.141 \\
\hline Observations & 814 & 814 & 814 & 814 & 814 & 814 \\
\hline
\end{tabular}




\begin{tabular}{lccccccc}
\hline \multicolumn{7}{c}{ Civil War Onset } \\
\hline & $(1)$ & $(2)$ & $(3)$ & $(4)$ & $(5)$ & $(6)$ & $(7)$ \\
& LS & Probit & Logit & Logit & Rare Event & Fixed & Fixed \\
& (Marginal & (Marginal & (Marginal & & Logit & Effects & Effects \\
& Effect) & Effect) & Effect) & & & Logit & Logit \\
3 -Year Commodity & $-0.027^{*}$ & $-0.034^{*}$ & $-0.034^{*}$ & $-1.351^{*}$ & $-1.248^{*}$ & $-1.355^{*}$ & $-6.992^{* *}$ \\
Price Growth & $(-1.82)$ & $(-1.75)$ & $(-1.90)$ & $(-1.73)$ & $(-1.65)$ & $(-1.84)$ & $(-2.39)$ \\
Country FE & No & No & No & No & No & Yes & Yes \\
Time Trends & No & No & No & No & No & No & Yes \\
Year FE & No & No & No & No & No & No & Yes \\
Observations & 814 & 814 & 814 & 814 & 814 & 814 & 814 \\
\hline
\end{tabular}

Note: The method of estimation in column (1) is least squares; in columns (2)-(7) maximum likelihood. Column (2) reports marginal effects estimates from a probit model; column (3) reports marginal effects estimates from a logit model; column (4) reports non-marginal effects estimates from a logit model; column (5) reports non-marginal effects estimates using the rare-events logit estimator (King and Zeng, 2001); columns (6) and (7) report non-marginal effects estimates from a conditional logit fixed effects regression. The dependent variable is civil war onset. 3-Year Commodity Price Growth is the commodity price growth rate between $t$ and $t-3$, using international commodity price data from IMF. *Significantly different from zero at the 90 percent confidence level, ** 95 percent confidence level, *** 99 percent confidence level.

Table 4. Economic Growth and Civil War Onset 1981-2006

\begin{tabular}{|c|c|c|c|}
\hline & $\underline{\text { GDP Growth }}$ & \multicolumn{2}{|c|}{ Civil War Onset } \\
\hline & (1) & (2) & (3) \\
\hline & LS & LS & 2SLS \\
\hline $\begin{array}{l}\text { 3-Year Commodity } \\
\text { Price Growth }\end{array}$ & $\begin{array}{l}0.028 * * * \\
\quad(3.97)\end{array}$ & & \\
\hline Per Capita GDP Growth & & $\begin{array}{c}-0.367 * * \\
(-2.57)\end{array}$ & $\begin{array}{c}-2.091 * * \\
{[0.025]}\end{array}$ \\
\hline Country FE & Yes & Yes & Yes \\
\hline Time Trends & Yes & Yes & Yes \\
\hline Year FE & Yes & Yes & Yes \\
\hline Adj. R-squared & 0.159 & 0.293 & . \\
\hline MSE & 0.243 & 0.313 & 0.195 \\
\hline Observations & 814 & 814 & 814 \\
\hline
\end{tabular}

Note: The method of estimation in columns (1)-(2) is least squares, column (3) two-stage least squares; below the least squares estimates we report tvalues (in brackets) based on Huber robust standard errors that are clustered at the country level; below the two-stage least squares estimates we report p-values [in square brackets] based on the Anderson-Rubin test of statistical significance. A key property of this test is that it is robust to weak instruments; 2SLS standard errors are not robust to weak instruments, and inference based on 2SLS can be very misleading as a result. See Andrews and Stock (2005) for a review of these issues. We implement a version of the Anderson-Rubin test that is robust to heteroskedasticity and arbitrary within-county correlation of the residuals. The dependent variable in column (1) is per capita GDP growth, columns (2)-(3) civil war onset. 3-Year Commodity Price Growth is the commodity price growth rate between $t$ and $t-3$, using international commodity price data from IMF. The instrumental variable in column (3) is the commodity price growth rate between $t$ and $t$-3. *Significantly different from zero at the 90 percent confidence level, ** 95 percent confidence level, ***99 percent confidence level. 
Table 5. Export Demand, Economic Growth, and Civil War Onset 1981-2006

\section{GDP Growth $\quad$ Civil War Onset}

(1)

(2)

LS

LS

(3)

$0.031 * * *$

$-0.061 * *$

$0.010 * * *$

$(17.63)$

$-0.006^{* * *}$

$(-5.85)$

Per Capita GDP Growth

Hansen J, p-value

Country FE

Time Trends

Year FE

Adj. R-squared

MSE

Observations

$\begin{array}{cc}\text { Yes } & \text { Yes } \\ \text { Yes } & \text { Yes } \\ \text { Yes } & \text { Yes } \\ 0.214 & 0.276 \\ 0.077 & 0.141 \\ 814\end{array}$

$-0.813^{* * *}$

[0.000]

0.1410

Yes

Yes

Yes

0.144

814

Note: The method of estimation in columns (1)-(2) is least squares, column (3) two-stage least squares; below the least squares estimates we report tvalues (in brackets) based on Huber robust standard errors that are clustered at the country level; below the two-stage least squares estimates of the endogenous variable we report p-values [in square brackets] based on the Anderson-Rubin test of statistical significance. A key property of this test is that it is robust to weak instruments; 2SLS standard errors are not robust to weak instruments, and inference based on 2SLS can be very misleading as a result. See Andrews and Stock (2005) for a review of these issues. We implement a version of the Anderson-Rubin test that is robust to heteroskedasticity and arbitrary within-county correlation of the residuals. The dependent variable in column (1) is per capita GDP growth, columns (2)-(3) civil war onset. 3-Year Commodity Price Growth is the commodity price growth rate between $t$ and $t$-3, using international commodity price data from IMF. The instrumental variable in column (3) is the commodity price growth rate between $t$ and $t$-3 and OECD growth *Significantly different from zero at the 90 percent confidence level, ** 95 percent confidence level, *** 99 percent confidence level. 
Table 6. Economic Growth and Civil Conflict Onset 1981-2006

\begin{tabular}{lcccc}
\hline & GDP Growth & \multicolumn{3}{c}{ Civil Conflict Onset } \\
\cline { 2 - 4 } & $(1)$ & $(2)$ & $(3)$ & LS \\
& LS & LS & LS & \\
3-Year Commodity & $0.025^{* *}$ & -0.033 & & \\
Price Growth & $(2.49)$ & $(-1.00)$ & & \\
OECD Growth & $0.010^{* * *}$ & $-0.005^{* * *}$ & & \\
& $(15.31)$ & $(-3.49)$ & $-0.310^{* *}$ & $-0.619^{* * *}$ \\
Per Capita GDP Growth & & & $(-2.23)$ & {$[0.000]$} \\
& & & & 0.5338 \\
Hansen J, p-value & & & Yes & Yes \\
Country FE & Yes & Yes & Yes & Yes \\
Time Trends & Yes & Yes & Yes & Yes \\
Year FE & Yes & Yes & 0.291 &. \\
Adj. R-squared & 0.274 & 0.285 & 0.192 & 0.194 \\
MSE & 0.068 & 0.193 & 688 & 688 \\
Observations & 688 & 688 & & \\
\hline
\end{tabular}

Note: The method of estimation in columns (1)-(3) is least squares, column (4) two-stage least squares; below the least squares estimates we report tvalues (in brackets) based on Huber robust standard errors that are clustered at the country level; below the two-stage least squares estimates we report p-values [in square brackets] based on the Anderson-Rubin test of statistical significance. A key property of this test is that it is robust to weak instruments; 2SLS standard errors are not robust to weak instruments, and inference based on 2SLS can be very misleading as a result. See Andrews and Stock (2005) for a review of these issues. We implement a version of the Anderson-Rubin test that is robust to heteroskedasticity and arbitrary within-county correlation of the residuals. The dependent variable in column (1) is per capita GDP growth, columns (2)-(4) civil conflict onset. 3Year Commodity Price Growth is the commodity price growth rate between $t$ and $t-3$, using international commodity price data from IMF. The instrumental variable in column (4) is the commodity price growth rate between $t$ and $t-3$ and OECD growth. *Significantly different from zero at the 90 percent confidence level, ** 95 percent confidence level, *** 99 percent confidence level. 


\begin{tabular}{ll}
\hline GDP Growth & Civil War Onset \\
\cline { 2 - 3 }
\end{tabular}

Panel A: Civil War Onset

(1)

LS

$0.025 * * *$
$(4.15)$

Per Capita GDP Growth

Hansen J, p-value

Country FE

Time Trends

Year FE

Adj. R-squared

MSE

Observations

\section{(a)} $x^{-2}$ Yes Yes 0.140 0.081
(2)

LS

$-0.017 *$

$(-1.84)$

$-0.002^{* *}$

$(-2.19)$

(3)

2SLS
$0.004 * * *$

(13.83)

$\begin{array}{lcc}\text { 3-Year Commodity } & 0.025^{* * *} & -0.017 * \\ \text { Price Growth } & (4.15) & (-1.84) \\ \text { OECD Growth } & 0.004 * * * & -0.002^{* *} \\ & (13.83) & (-2.19)\end{array}$

3-Year Commodity Price Growth $0.028^{* * *}$

OECD Growth

Per Capita GDP Growth

Hansen J, p-value

Country FE

Time Trends

Year FE

Adj. R-squared

MSE

Observations

Yes
Yes
Yes
0.153
0.132
1332

Panel B

$(2)$
LS
$-0.025^{*}$
$(-1.85)$
$-0.002^{* *}$
$(-2.45)$

$-0.215 * *$

$-0.558 * * *$

$(-2.17)$

[0.004]

0.6333

Yes

Yes

Yes

Yes

Yes

0.165

0.131

0.134

1332

1332

Panel B: Civil Conflict Onset

(4)

2SLS

LS

$\begin{array}{cc}-0.159^{* *} & -0.648^{* *} \\ (-2.16) & {[0.015]} \\ & 0.4794 \\ \text { Yes } & \text { Yes } \\ \text { Yes } & \text { Yes } \\ \text { Yes } & \text { Yes } \\ 0.233 & \cdot \\ 0.195 & 0.198 \\ 1150 & 1150\end{array}$

Note: The method of estimation in columns (1)-(3) is least squares, column (4) two-stage least squares; below the least squares estimates we report tvalues (in brackets) based on Huber robust standard errors that are clustered at the country level; below the two-stage least squares estimates we report p-values [in square brackets] based on the Anderson-Rubin test of statistical significance. A key property of this test is that it is robust to weak instruments; 2SLS standard errors are not robust to weak instruments, and inference based on 2SLS can be very misleading as a result. See Andrews and Stock (2005) for a review of these issues. We implement a version of the Anderson-Rubin test that is robust to heteroskedasticity and arbitrary within-county correlation of the residuals. The dependent variable in column (1) is per capita GDP growth; Panel A, columns (2)-(4) civil war onset and Panel B, columns (2)-(4) civil conflict onset. 3-Year Commodity Price Growth is the commodity price growth rate between $t$ and $t$-3, using international commodity price data from UNCTAD. The instrumental variable in column (4) is the commodity price growth rate between $t$ and $t$ - 3 and OECD growth *Significantly different from zero at the 90 percent confidence level, ** 95 percent confidence level, *** 99 percent confidence level. 


\section{Appendix Table 1. Commodity Exports of Sub-Saharan Countries}

\begin{tabular}{|c|c|}
\hline Country & Commodities \\
\hline Angola & Oil (93) \\
\hline Benin & Cotton (42), Oil (22) \\
\hline Botswana & Nickel (10), Copper (6)* [2000] \\
\hline Burkina Faso & Cotton (57), Gold (20) \\
\hline Burundi & Coffee (75), Tea (10) \\
\hline Cameroon & Oil (50), Wood $(9)^{*}$, Cocoa $(8)^{*+}$, Aluminium $(7)^{*}$, Coffee $(8)^{*}$, Cotton $(3)^{*}[1990]$ \\
\hline Central African Republic & Coffee (11), Wood (19)*, Cotton (11)*, Tobacco (1)* [1993] \\
\hline Chad & Cotton (85) \\
\hline Democratic Republic of Congo & Copper (46), Oil (10) \\
\hline Republic of Congo & Oil (85) \\
\hline Ethiopia & Coffee (45), Sugar (2)* [1993] \\
\hline Gabon & Oil (75), Wood (11) \\
\hline Gambia & Groundnuts (20), Fish (32), Cotton (3) \\
\hline Ghana & Cocoa (29)+, Aluminium (18), Gold (13), Wood (11), \\
\hline Guinea & Aluminium (64)*, Coffee (6)*, Gold (2)*, Cotton (1)* [1995] \\
\hline Guinea-Bissau & Oil (14), Fish (28), Banana (50)*, Wood (4)*, Cotton (2)* [1995] \\
\hline Ivory-Coast & Cocoa $(33)+$, Wood (16), Coffee (9)*, Oil (9)* [1995] \\
\hline Kenya & Tea (19)+, Oil (13), Coffee (14), Fish(2)* [1990] \\
\hline Liberia & Iron $(62)^{*}$, Coffee $(6)^{*}$, Cocoa $(3)^{*}[1984]$ \\
\hline Madagascar & Coffee (13), Fish (14), Sugar (7)*, Cotton (4)*, Oil* (1) [1990] \\
\hline Malawi & Tobacco (68), Tea (11) \\
\hline Mali & Cotton (62) \\
\hline Mauritania & Iron (55), Fish (35) \\
\hline Mozambique & Fish (36), Cotton (8)*, Sugar (7)* [1994] \\
\hline Namibia & Fish $(18)^{*}$, Uranium $(2)^{*+}$, Gold $(2)^{*}$, Copper $(1)^{*}[2000]$ \\
\hline Niger & Uranium $(83)+$ \\
\hline Nigeria & Oil $(93)+$ \\
\hline Rwanda & Coffee (61), Gold (20) \\
\hline Senegal & Oil (12), Groundnuts (17), Fish (28), Phosphates (6)*, Cotton (1)* [1990] \\
\hline Sierra Leone & Aluminium (19), Cocoa (15)*, Coffee (4)*, Fish (1)* [1984] \\
\hline Somalia & Livestock $(90) *[1982]$ \\
\hline South Africa & Gold $(50)^{*+}$, Iron $(36)^{*}$, Aluminium $(15)^{*}[2000]$ \\
\hline Sudan & Cotton (42), Sugar (6)* [1990] \\
\hline Swaziland & Sugar (22), Cotton (2)* [1990] \\
\hline Tanzania & Cotton (18), Coffee (19), Sugar (13), Gold (5) \\
\hline Togo & Cotton (21), Phosphates (44) \\
\hline Uganda & Coffee (74) \\
\hline Zambia & Copper (88) \\
\hline Zimbabwe & Tobacco $(24)+$, Iron $(10)^{*}$, Cotton $(6)^{*}$, Copper $(2)^{*}[1990]$ \\
\hline
\end{tabular}

Note: The data comes predominantly from Deaton (1999) and refers to 1990. When listed commodities comprised less than two thirds of total exports according to the United Nations Commodity Trade Statistics Database, we added commodities using data for the year (indicated in brackets) closest to 1990 . Commodity data added to Deaton is marked by an *. Commodities produced in a country that constitute more than $3 \%$ of the world commodity supply are marked by a + (based on the information provided by the US Government International Energy Statistics (oil), International Cocoa Association (cocoa), International Coffee Association (coffee), FAO (tea), WHO (tobacco), World Gold Council (gold), and World Nuclear Association (uranium)). 